\title{
MANFAAT EKONOMI PENERAPAN STANDAR DENGAN PENDEKATAN ISO METHODOLOGY - ECONOMIC BENEFIT STANDARD (Studi Kasus: UD. Deva Elektronik)
}

\author{
Calvin William Santosa ${ }^{* 1}$, Fakhrina Fahma ${ }^{2}$ \\ ${ }^{1,2}$ Teknik Industri, Fakultas Teknik, Universitas Sebelas Maret, Jl. Ir. Sutami No. 36 A, Surakarta, 57126, \\ Indonesia \\ Email: calvinwilliamsantosa@gmail.com ${ }^{1}$,fakhrinafahma@staff.uns.ac.id ${ }^{2}$
}

\begin{abstract}
Abstrak
UD. Deva Elektronik merupakan salah satu Usaha Kecil dan Menengah (UKM) yang bergerak di bidang perakitan elektronik yaitu tv tabung di Surakarta. UKM ini telah menerapkan standar untuk produk tv tabung yaitu SNI 046253-2003 sejak tahun 2016, namun manfaat dari penerapan standar ini belum diukur secara ekonomi. Oleh karena itu, perlu dilakukan penilaian secara ekonomi dari manfaat penerapan standar tersebut. Tujuan penelitian ini untuk mengevaluasi manfaat ekonomi dari penerapan standar yang dirasakan oleh UD. Deva Elektronik yang bergerak di bidang perakitan elektronik setelah menerapkan SNI 04-6253-2003 dengan menggunakan pendekatan ISO Methodology - Economic Benefits Standard. Pendekatan ISO Methodology meliputi penentuan value chain, analisa value drivers, identifikasi dampak dari standar, serta penilaian dan konsolidasi hasil. Manfaat dari penerapan standar pada UD. Deva Elektronik dapat dikatakan sudah cukup maksimal. Hal ini dapat terlihat dari hasil yang diperoleh dengan memiliki lima fungsi bisnis (value chain) yaitu inbound logistic, operations, outbond logistic, service, dan procurement yang memberikan dampak dari penerapan standar. Total keseluruhan manfaat ekonomi yang diperoleh UD. Deva Elektronik menjadi sebesar Rp. 249.920.000. Dengan total manfaat ekonomi yang diperoleh dapat dikatakan keuntungan yang diperoleh telah sebanding dengan biaya yang dikeluarkan untuk memperoleh SNI dan biaya lainnya terkait resertifikasi SNI setiap tahunnya.
\end{abstract}

Kata kunci: penerapan standar, manfaat ekonomi, ISO methodology

\begin{abstract}
UD. Deva Elektronik is one of the Small and Medium Enterprises (SMEs) which is engaged in assembling electronics, namely tube tv in Surakarta. This SMEs has applied the standard for tube tv products, namely SNI 046253-2003 since 2016, but the benefits of implementing this standard have not been measured economically. Therefore, it is necessary to conduct an economic assessment of the benefits of implementing these standards. The purpose of this study is to evaluate the economic benefits of implementing the standards perceived by UD. Deva Elektronik which is engaged in electronic assembly after implementing SNI 04-6253-2003 by using the ISO Methodology - Economic Benefits Standard approach. The ISO Methodology approach includes determining the value chain, analyzing value drivers, identifying the impact of the standard, as well as evaluating and consolidating results. Benefit from implementing standards at UD. Deva Elektronik can be said to have been quite maximal. This can be seen from the results obtained by having five business functions (value chain) namely inbound logistics, operations, outbound logistics, service, and procurement which have an impact on the implementation of standards. The total economic benefits obtained by UD. Deva Elektronik became Rp. 249,920,000. With the total economic benefits obtained, it can be said that the benefits obtained are comparable to the costs incurred to obtain SNI and other costs related to SNI recertification every year.
\end{abstract}

Keywords: application of standards, economic benefits, ISO methodology

\section{Pendahuluan}

Perkembangan perdagangan internasional pada saat ini telah mengarah pada bentuk perdagangan bebas yang memiliki tujuan untuk terciptanya perdagangan bebas hambatan. Perdagangan bebas yang ada dapat mempengaruhi nilai ekspor dan impor sebuah negara. Indonesia sebagai salah satu negara dengan penduduk terpadat di dunia, memiliki potensi yang besar sebagai pasar dan produsen untuk berbagai jenis produk yang nantinya produk-produk tersebut akan bersaing dengan produk-produk impor yang semakin banyak masuk ke dalam negeri.

Usaha Kecil dan Menengah (UKM) menjadi salah satu pilar perekonomian Indonesia berperan dan berpengaruh dalam perdagangan global. Peningkatan daya saing produk UKM menjadi salah satu faktor penting untuk berkompetisi dalam perdagangan global. Peningkatan daya saing produk dapat dilakukan melalui

* Penulis korespondensi 
penerapan standar. Badan Standardisasi Nasional (BSN) selaku lembaga Pemerintah Non Kementerian yang memiliki tugas untuk mengembangkan standardisasi di Indonesia, terus melakukan berbagai upaya untuk meningkatkan kesadaran masyarakat akan pentingnya standar produk sebuah industri. Standardisasi adalah proses merencanakan, merumuskan, menetapkan, menerapkan, memberlakukan, memelihara, dan mengawasi Standar yang dilaksanakan secara tertib dan bekerja sama dengan semua Pemangku Kepentingan (UU Nomor 20 tahun 2014). Penerapan SNI memungkinkan perusahaan melakukan penyederhanaan dalam proses operasional pada semua tingkatan, meningkatkan efisiensi dan produktivitas, serta meminimalkan kecelakaan kerja. (Perwitasari et al, 2019). BSN menerbitkan SNI 04-6253-2003 yang mengenai 'Peralatan audio, video dan elektronika sejenis Persyaratan keselamatan", diadopsi dengan beberapa modifikasi (National Differences) dari standar International Electrotechnical Commission (IEC) Publikasi 60065 (2001-12) dengan Judul “Audio, video and similar electronic apparatus - Safety requirements". Standar Nasional Indonesia (SNI) 046253-2003 merupakan label standar yang diterapkan pada peralatan elektronik yang didesain untuk disuplai dari suplai utama, dari peralatan suplai, dari baterai atau dari suplai daya jauh dan ditujukan untuk menerima, membangkitkan, merekam atau mereproduksi ulang secara berturut-turut sinyal audio, video dan sinyal terkait. Standar ini juga diterapkan pada peralatan yang didesain secara khusus sebagai kombinasi peralatan tersebut di atas. Standar ini terutama ditujukan untuk peralatan yang digunakan untuk rumah tangga dan penggunaan umum serupa tetapi bisa juga digunakan di tempat-tempat umum seperti sekolah, teater, rumah ibadah dan tempat kerja.

Dalam perkembangannya penerapan standar oleh UKM menemui beberapa kendala, seperti keterbatasan jumlah UKM yang berminat menerapkan standar, proses sertifikasi yang tidak mudah dan besarnya biaya pengujian atau sertifikasi yang dinilai mahal dan bersifat menambah biaya produksi (Meylani et al, 2012). Biaya yang cukup tinggi dalam penerapan standar belum tentu sebanding dengan dampak ekonomi yang akan didapatkan oleh industri tersebut dalam jangka waktu yang akan datang.

Pada tahun 2010, Organization for Standardization (ISO) telah mengembangkan suatu metode untuk menghitung manfaat ekonomi dari penerapan standar, metode ini disebut dengan ISO Methodology - Economic
Benefit Standard (EBS). Tujuan dari metodologi tersebut antara lain untuk mengukur dampak dari standar pada penciptaan nilai-nilai organisasi dengan penekanan pada bisnis organisasi, untuk memberikan kriteria yang jelas dan terkelola dengan baik bagi pengambil keputusan untuk menilai hal-hal yang berhubungan dengan standar, dan untuk memberikan pedoman dalam menilai manfaat dari standar pada sektor industri tertentu.

ISO Methodology menyediakan kriteria kerangka konsisten, petunjuk dan alat untuk menilai keuntungan ekonomi standar dari perspekstif organisasi individual yaitu perusahaan yang berorientasi mencari keuntungan atau perusahaan publik. Penerapan ISO Methodology dapat membantu perusahaan mengetahui lebih baik aktivitas dan proses organisasi yang berhubungan dengan penggunaan standar dengan gambaran peningkatan kinerja dan memaksimalkan keuntungan yang diturunkannya.

Pendekatan ISO Methodology terdiri dalam lima tahapan yaitu pertama menentukan value chain yaitu menggunakan model value chain ISO Methodology 2.0 yang terdiri dari sembilan fungsi bisnis kemudian akan dipilih fungsi bisnis yang berpengaruh terhadap penerapan SNI 04-6253-2003. Tahap kedua adalah analisis value drivers, yaitu kemampuan penting dari suatu organisasi bisnis yang dapat memberikan keuntungan kompetitif terhadap organisasi tersebut, analisis value drivers ditentukan dengan acuan sembilan fungsi bisnis value chain. Tahap ketiga yaitu menentukan key performance indicator, dalam penentuan indicator ini diturunkan langsung dari value drivers. Tahap keempat yaitu melakukan indentifikasi dampak standarisasi. Tahap kelima yaitu penilaian konsolidasi hasil. Dalam penelitian ini data yang ada diperoleh berdasarkan hasil dari studi pustaka dan wawancara dengan narasumber dari UD. Deva Elektronik.

ISO Methodology telah digunakan dalam beberapa penelitian untuk mengukur dampak ekonomi dari penerapan standar. Penelitian sebelumnya yang berhubungan dengan dampak ekonomi dan ISO Methodology dilakukan oleh Susanto et al (2017) yang mengukur dampak ekonomi dari beberapa jenis UKM yang berbeda. Pada penelitian tersebut mengambil sampel UKM di bidang makanan dan produk bahanbahan spa. Selain itu Mulyono \& Pudjiastuti (2013) juga menggunakan pendekatan ISO Methodology untuk mengukur dampak ekonomi penerapan SNI salah satu perusahaan bidang makanan di Jakarta dan Surabaya. Berikut adalah tabel perbandingan penelitian terdahulu tentang standardisasi di Indonesia. 
Tabel 1. Perbandingan Penelitian Terdahulu Tentang Standardisasi di Indonesia

\begin{tabular}{|c|c|c|c|c|c|}
\hline No & Judul & Peneliti & Metode & Bahasan & Hasil \\
\hline 1 & $\begin{array}{l}\text { MANFAAT EKONOMI } \\
\text { PENERAPAN STANDAR } \\
\text { PADA USAHA KECIL } \\
\text { MENENGAH } \\
\text { MENGGUNAKAN ISO } \\
\text { METHODOLOGY }\end{array}$ & $\begin{array}{l}\text { Danar A. Susanto, } \\
\text { Febrian Isharyadi dan } \\
\text { Mangasa Ritonga }\end{array}$ & ISO Methodology & $\begin{array}{l}\text { Manfaat } \\
\text { standardisasi } \\
\text { UKM }\end{array}$ & \begin{tabular}{lr}
\multicolumn{2}{l}{ Menghasilkan nilai manfaat } \\
penerapan standar yang \\
diukur dalam nilai ekonomi \\
(rupiah) & untuk \\
menunjukkan & bahwa \\
standar & memberikan \\
kontribusi & manfaat \\
ekonomi &
\end{tabular} \\
\hline 2 & $\begin{array}{l}\text { MANFAAT EKONOMI } \\
\text { PENERAPAN STANDAR } \\
\text { DI SEKTOR MAKANAN } \\
\text { MENGGUNAKAN } \\
\text { METODOLOGI ISO }\end{array}$ & $\begin{array}{l}\text { Ary Budi Mulyono dan } \\
\text { Untari Pudjiastuti }\end{array}$ & ISO Methodology & 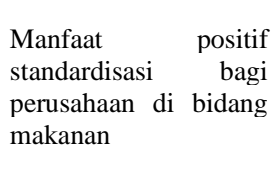 & $\begin{array}{l}\text { Mengidentifikasi dampak } \\
\text { dari penerapan standar dan } \\
\text { menghasilkan nilai } \\
\text { keuntungan ekonomi dari } \\
\text { penerapan standar }\end{array}$ \\
\hline 3 & $\begin{array}{l}\text { MANFAAT EKONOMI } \\
\text { PENERAPAN STANDAR } \\
\text { DENGAN } \\
\text { PENDEKATAN ISO } \\
\text { METHODOLOGY - } \\
\text { ECONOMIC BENEFIT } \\
\text { STANDARD (Studi Kasus: } \\
\text { UD. Deva Elektronik) }\end{array}$ & Penulis & ISO Methodology & $\begin{array}{lr}\text { Manfaat } & \text { ekonomi } \\
\text { penerapan } & \text { standar bagi } \\
\text { UKM } & \text { perakit } \\
\text { elektronik } & \end{array}$ & $\begin{array}{lr}\text { Menghasilkan } & \text { manfaat } \\
\text { ekonomi yang } & \text { diperoleh } \\
\text { UD. Deva Elektronik untuk } \\
\text { menunjukkan } & \text { bahwa } \\
\text { standar } & \text { memberikan } \\
\text { kontribusi } & \text { manfaat } \\
\text { ekonomi } & \end{array}$ \\
\hline
\end{tabular}

UD. Deva Elektronik merupakan salah satu UKM yang bergerak di bidang perakitan elektronik yaitu tv tabung di Surakarta yang berlokasi di Jl. Sambeng No. 6e RT. 06 RW. 02 Mangkubumen, Banjarsari, Surakarta. UKM ini telah menerapkan standar untuk produk tv tabung yaitu SNI 04-6253-2003 sejak tahun 2016, namun manfaat dari penerapan standar ini belum diukur secara ekonomi. Oleh karena itu, perlu dilakukan penilaian secara ekonomi dari manfaat penerapan standar di bidang elektronik pada UD. Deva Elektronik tersebut. Penelitian ini bertujuan untuk mengevaluasi manfaat penerapan standar yang dirasakan oleh UD. Deva Elektronik setelah menerapkan SNI 04-6253-2003 dengan menggunakan pendekatan ISO Methodology - Economic Benefits Standard berdasarkan value chain dan value drivers yang kemudian akan dihasilkan nilai manfaat dari penerapan standar yang diukur dalam nilai ekonomi atau rupiah.

\section{Metode Penelitian}

Metode penelitian ini dibagi menjadi tiga tahap yaitu tahap awal, tahap pengumpulan dan pengolahan data, dan tahap akhir. Flowchart metodologi penelitian ditampilkan pada Gambar 1.

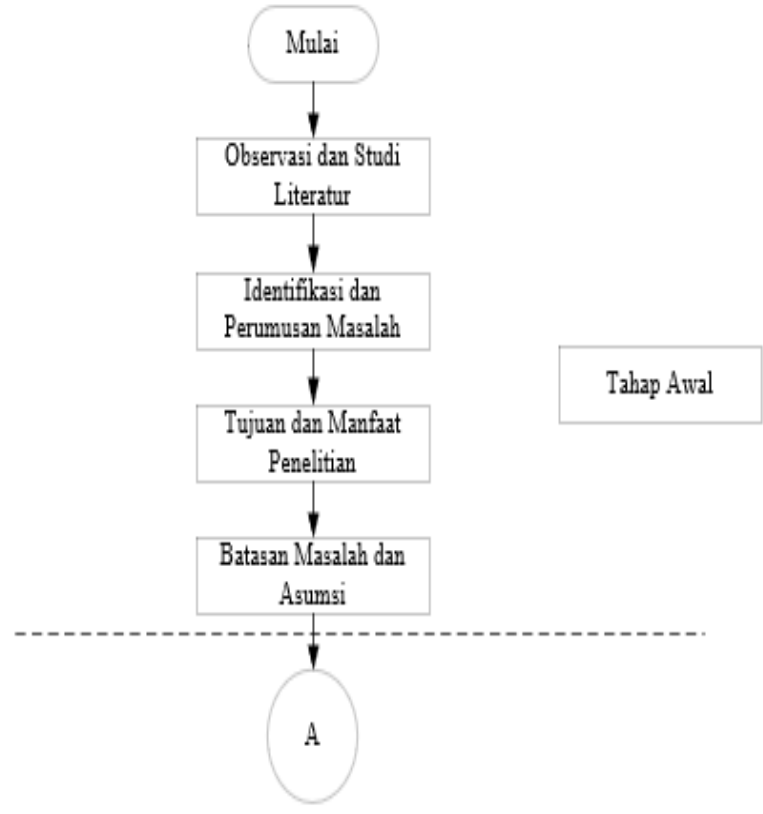

Gambar 1. Flowchart Metodologi Penelitian 


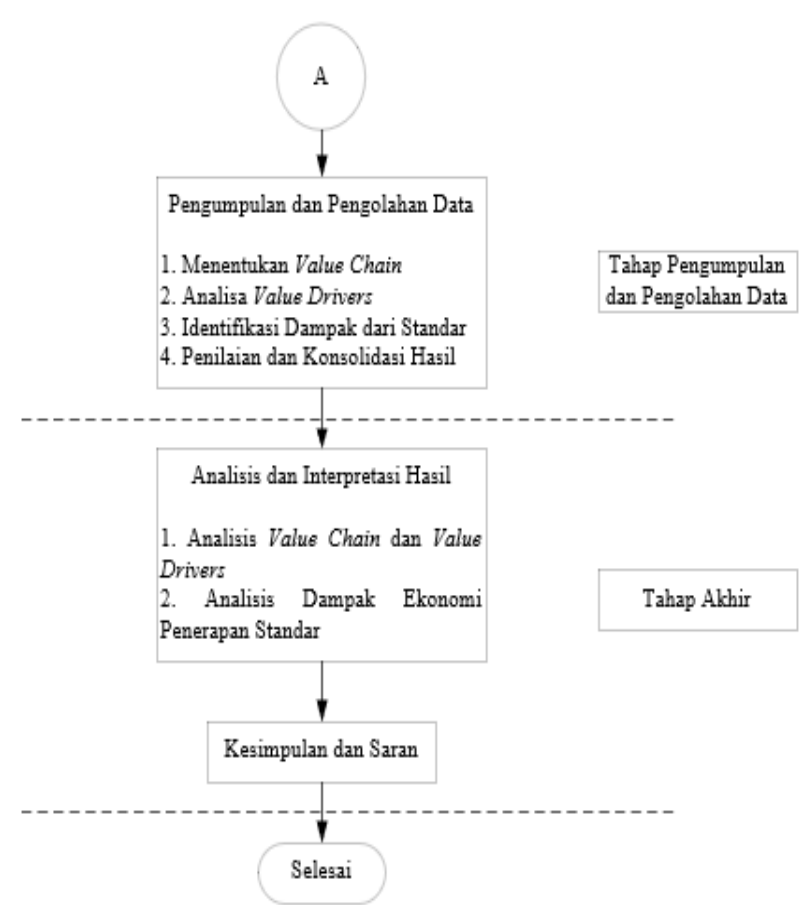

Gambar 1. Flowchart Metodologi Penelitian (Lanjutan)

Tahap awal penelitian yang menjelaskan mengenai proses observasi dan studi literatur, perumusan masalah, penentuan tujuan, manfaat penelitian serta penentuan batasan dan asumsi yang digunakan dalam penelitian. Penelitian diawali dengan pengenalan kondisi industri perakit elektronik secara umum. Pengamatan kondisi industri perakit elektronik bertujuan untuk memberikan gambaran umum bagaimana kondisi sesungguhnya sistem di dalam industri tersebut berjalan, kemudian memberikan gambaran umum mengenai pentingnya penerapan SNI 04-6253-2003. Studi literatur dilakukan untuk mendapatkan informasi dari beberapa jurnal penelitian dan sumber literatur. Studi literatur dengan mencari beberapa jurnal dan sumber literatur yang berhubungan dengan Standar Nasional Indonesia (SNI), ISO Methodology, dan sebagainya. Hasil dari studi literatur digunakan sebagai acuan dan referensi dalam membuat latar belakang masalah dan landasan teori dalam penelitian ini. Masalah yang telah diidentifikasi pada proses sebelumnya digunakan sebagai dasar dalam penyusunan rumusan masalah. Perumusan masalah dilakukan setelah hal yang melatarbelakangi penelitian ditentukan. Berdasarkan rumusan masalah yang telah dibuat, maka penelitian masuk ke dalam tahap menetapkan tujuan yang ingin dicapai dan manfaat dari penelitian. Penerapan batasan masalah ini agar arah penelitian menjadi lebih terfokus.

Tahap selanjutnya mengenai proses pengumpulan data dan pengolahan data dalam penelitian. Diawali dengan menentukan value chain penerapan standar oleh UKM perakit elektronik. Dengan melakukan perancangan alat ukur kuesioner untuk mengetahui pengaruh atau manfaat dari penerapan SNI 04-62532003. Kuesioner ini merupakan kuesioner dikotomi yang digunakan untuk menentukan potensi value chain. Penyusunan kuesioner yang digunakan berdasarkan model value chain Porter. Berikut adalah Gambar 2 yang memaparkan model value chain Porter.

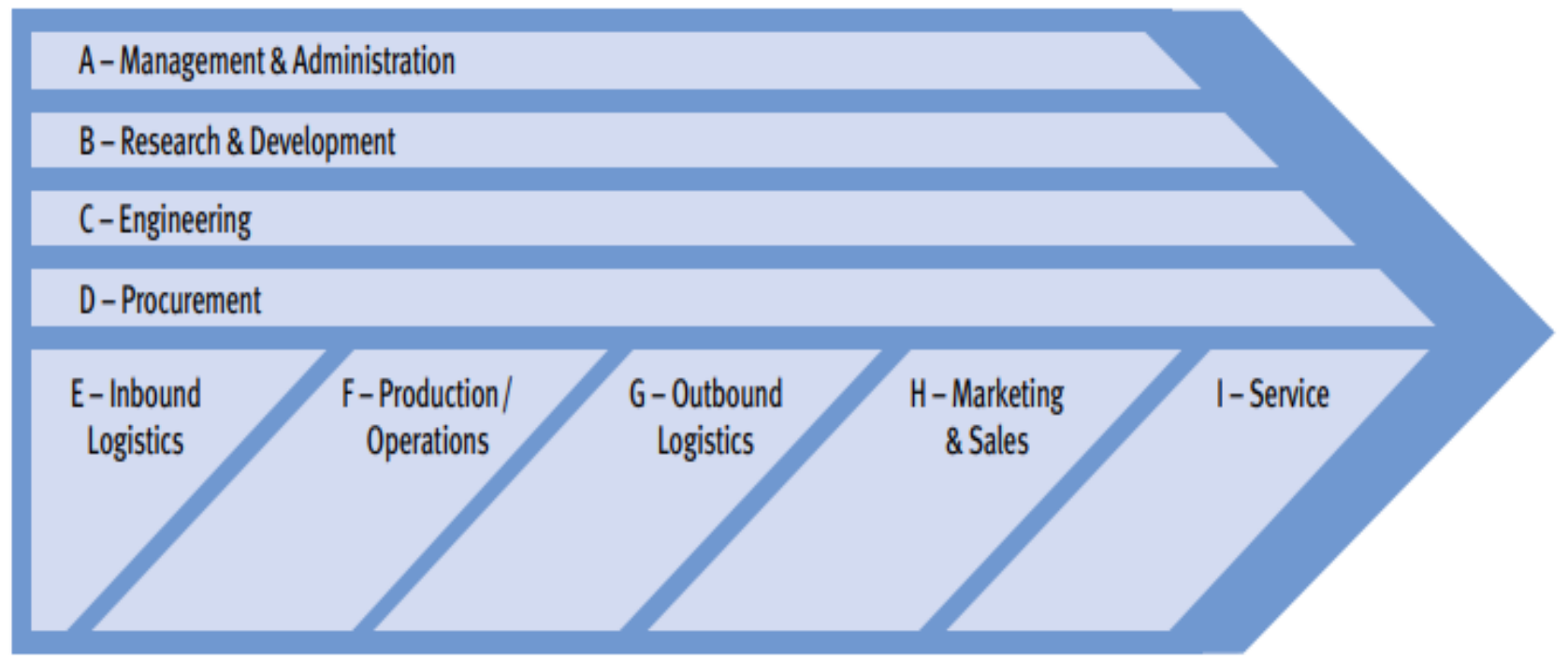

Gambar 2. Model Value Chain Porter

(Sumber: International Organization for Standardization, 2014)

Model value chain Porter terdiri dari 9 fungsi bisnis (value chain) meliputi inbound logistic adalah aktivitas yang dilakukan berhubungan dengan penerimaan, penyimpanan, dan distribusi komponen bahan baku, operations adalah aktivitas yang mentransformasikan input (bahan baku) menjadi output (barang yang sudah jadi), outbound logistic adalah aktivitas yang berhubungan dengan menyebarkan (distribusi) produk/jasa kepada pelanggan, marketing and sales adalah kegiatan yang berhubungan dengan pemasaran dan penjualan, diantaranya penelitian pasar (riset pasar) dan promosi produk elektronik, service adalah egiatan yang berhubungan dengan penyedia layanan untuk meningkatkan pemeliharaan produk seperti instalasi, 
pelatihan, perbaikan, suplai bahan, dan perawatan, engineering terdiri atas sistem, fungsi, dan setting dari alat yang digunakan, management and administration berhubungan dengan aktivitas recruitment, pengembangan, pelatihan, memotivasi, pemberian penghargaan kepada karyawan, dan dokumen administrasi, research and development $(\mathrm{RnD})$ adalah aktivitas yang terkait produk, proses perbaikan, perancangan peralatan, pengembangan dan inovasi produk, dan procurement adalah kegiatan yang berhubungan dengan bagaimana sumber daya diperoleh diantaranya fungsi pembelian bahan baku yang digunakan. Selanjutnya, dilakukan pengambilan data terkait value drivers penerapan standar berdasarkan hasil value chain yang terpilih melalui kuesioner dengan menggunakan metode wawancara. Pengambilan data dilakukan terhadap UKM perakit elektronik yang telah melakukan penerapan SNI 04-6253-2003 yaitu UD. Deva Elektronik. Adapun yang menjadi responden dalam penelitian ini adalah pemilik dari UD. Deva Elektronik. Setelah dihasilkan potensi value chain, value drivers penerapan standar, dilakukan penyusunan pertanyaan terbuka berdasarkan hasil value chain dan value drivers untuk mengetahui faktor-faktor yang berpengaruh dan manfaat ekonomi penerapan standar dari aspek ekonomi. Kemudian, dilakukan penilaian kontribusi manfaat ekonomi penerapan standar. Manfaat ekonomi penerapan standar yang diukur merupakan perubahan nilai kuantitatif dari indikator terpilih yang diperoleh dari perbandingan sebelum dan setelah menggunakan standar. Selain itu juga dilakukan pemisahan apakah perubahan nilai kuantitatif tersebut seluruhnya disebabkan oleh penerapan standar atau terdapat faktor pengaruh yang lain. Perhitungan kontribusi manfaat ekonomi dari penerapan standar dilakukan pada tiap indikator operasional yang kemudian digabungkan sehingga menghasilkan total manfaat ekonomi penerapan standar.

Tahap terakhir mengenai análisis yang dilakukan setelah pengolahan data, analisis pada tahap ini adalah analisis value chain dan value drivers dan analisis dampak ekonomi penerapan standar. serta kesimpulan mencakup dari tujuan yang ingin dicapai dan dilakukan terhadap pengolahan data dan analisis yang telah dilakukan. Pada tahap ini juga berisi saran sebagai masukan yang diharapkan berguna untuk pihak terkait dengan penelitian ini.

\section{Hasil dan Pembahasan}

\subsection{Profil UKM}

Berikut adalah profil dari UD. Deva Elektronik

$\begin{array}{ll}\text { Nama UKM } & \text { : UD. Deva Elektronik } \\ \text { Bentuk Usaha } & \text { : Usaha Dagang (UD) } \\ \text { Nama Pemilik } & \text { : Suyatno } \\ \text { Alamat UKM } & \text { : Jl. Sambeng No. 6e RT. 06 } \\ \text { RW. 02 Mangkubumen, Banjarsari, Surakarta } \\ \begin{array}{ll}\text { Jumlah Tenaga Kerja: } 15 \text { orang } \\ \text { Pemasaran }\end{array}\end{array}$

\subsection{Pembahasan}

Model value chain yang digunakan adalah model value chain berdasarkan ISO Methodology 2.0 yang terdiri dari sembilan fungsi bisnis yang dapat mewakili value chain dari UD. Deva Elektronik. Value chain penerapan standar pada UD. Deva Elektronik ditampilkan pada Tabel 2.

Tabel 2. Value Chain UD. Deva Elektronik

\begin{tabular}{|c|c|c|c|c|c|c|c|c|}
\hline \multicolumn{9}{|c|}{ Value Chain } \\
\hline Inbound Logistic & Operations & $\begin{array}{l}\text { Outbond } \\
\text { Logistic }\end{array}$ & $\begin{array}{c}\text { Marketing } \\
\text { and Sales }\end{array}$ & Service & $\begin{array}{c}\text { Management } \\
\text { and } \\
\text { Administartion }\end{array}$ & $\begin{array}{c}\text { Research } \\
\text { and } \\
\text { Development }\end{array}$ & Procurement & Engineering \\
\hline$\checkmark$ & $\checkmark$ & $\checkmark$ & & $\checkmark$ & & & $\checkmark$ & \\
\hline
\end{tabular}

Berdasarkan hasil analisa dari studi pustaka, kuesioner, dan wawancara yang dilakukan dapat diketahui potensi dampak ekonomi dari penerapan standar pada value chain. UD. Deva Elektronik memiliki lima value chain dari sembilan value chain yang ada. Pertama adalah inbound logistic yang merupakan aktivitas yang dilakukan berhubungan penerimaan, penyimpanan, dan distribusi komponen bahan baku. Kedua adalah operations yang merupakan aktivitas yang mentransformasikan input (bahan baku) menjadi output (barang yang sudah jadi). Ketiga adalah outbond logistic yang merupakan aktivitas yang berhubungan dengan menyebarkan (distribusi) produk/jasa kepada pelanggan.
Keempat adalah service yang merupakan kegiatan yang berhubungan dengan penyedia layanan untuk meningkatkan pemeliharaan produk seperti instalasi, pelatihan, perbaikan, suplai bahan, dan perawatan. Kelima adalah procurement yang merupakan kegiatan yang berhubungan dengan bagaimana sumber daya diperoleh diantaranya fungsi pembelian bahan baku yang digunakan.

Value drivers adalah kemampuan penting dari suatu organisasi bisnis yang dapat memberikan keuntungan kompetitif terhadap organisasi tersebut. Dampak dari standar dalam proses operasi perusahaan dapat dinilai melalui value drivers tersebut atau dari nilai kreasi yang 
dapat diciptakan oleh perusahaan dengan adanya penerapan standar.

Berdasarkan hasil kuesioner dan wawancara dengan expert dari UD. Deva Elektronik diperoleh value drivers untuk masing-masing value chain yang ada. Pertama adalah inbound logistic dengan value drivers kualitas cara penyimpanan. Kedua adalah operations dengan value drivers efisiensi produksi. Ketiga adalah outbond logistic dengan value drivers kualitas produk. Keempat adalah service dengan value drivers kualitas pelayanan. Kelima adalah procurement dengan value drivers kualitas bahan baku.
Penggunaan standar yang telah diidentifikasi dalam fungsi bisnis terpilih yang terdapat pada UD. Deva Elektronik memiliki dampak pada fungsi bisnis. Dampak penerapan standar pada UD. Deva Elektronik ditampilkan pada Tabel 3.

Tabel 3. Dampak Penerapan Standar UD. Deva Elektronik

\begin{tabular}{|c|c|c|c|}
\hline Standar SNI & Value Chain & Value Drivers & Dampak \\
\hline \multirow{5}{*}{ SNI 04-6253-2003 } & $\begin{array}{l}\text { Inbound } \\
\text { Logistic }\end{array}$ & Kualitas Cara Penyimpanan & $\begin{array}{c}\text { Mempermudah proses pencarian bahan baku dan penyimpanan } \\
\text { bahan baku lebih baik }\end{array}$ \\
\hline & Operations & Efisiensi Produksi & Peningkatan jumlah produksi \\
\hline & $\begin{array}{l}\text { Outbond } \\
\text { Logistic }\end{array}$ & Kualitas Produk & Penurunan jumlah reject \\
\hline & Service & Kualitas Pelayanan & Jumlah keluhan menurun \\
\hline & Procurement & Kualitas Bahan Baku & Penurunan jumlah bahan baku/komponen yang rusak \\
\hline & & & $\begin{array}{l}\text { Setelah diketahui value drivers dan dampak dari } \\
\text { setiap value chain, dilakukan identifikasi indikator } \\
\text { operasional pada UD. Deva Elektronik. Indikator } \\
\text { operasional pada UD. Deva Elektronik dutampilkan pada } \\
\text { Tabel } 4 \text {. }\end{array}$ \\
\hline
\end{tabular}

Tabel 4. Indikator Operasional

\begin{tabular}{llc}
\hline Value Chain $\quad$ Value Drivers & Dampak
\end{tabular}

Inbound

Logistic

Kualitas Cara Penyimpanan

Mempermudah proses pencarian bahan baku dan penyimpanan bahan baku lebih baik
Dengan penerapan standar, penataan gudang lebih teratur dan memberikan manfaat dalam pencarian komponen lebih cepat. Setelah menerapkan standar, waktu yang dibutuhkan untuk melakukan pencarian komponen lebih cepat 5 menit per harinya

Peningkatan proses produksi setelah menerapkan SNI dapat dilihat dari meningkatnya jumlah produk yang dapat dihasilkan dalam satu bulan. Sebelum menerapkan SNI, jumlah produksi sebesar 800 unit/bulan. Setelah menerapkan SNI, jumlah produksi meningkat menjadi 1200 unit/bulan 
dengan baik. Hal ini dapat dilihat dari berkurangnya jumlah produk yang mengalami cacat atau reject. Sebelum menerapkan SNI jumlah produk reject dapat mencapai $5 \%$. Setelah menerapkan standar, produk reject menurun menjadi $2 \%$

Kepuasan pelanggan dapat dilihat dari jumlah keluhan yang terjadi didalam pengiriman produk. Keluhan yang dimaksud yaitu keluhan produk rusak karena kemasan basah atau produk tidak bisa digunakan. Sebelum menerapkan standar, rasio klaim pertahun sebesar 5\%. Namun setelah menerapkan standar dan melakukan peningkatan berkelanjutan, keluhan dapat diturunkan menjadi $2 \%$

Dengan menerapkan standar, penataan gudang lebih teratur dan memberikan efek berkurangnya jumlah casing sebagai komponen yang rusak dalam satu tahun dimana sebelumnya casing yang rusak per tahun sekitar 25 pcs, saat ini berkurang menjadi sekitar 8 pcs yang rusak per tahun.

Berdasarkan hasil wawancara dengan expert UD, Deva Elektronik diperoleh bahwa indikator operasional dari value chain inbound logistic adalah waktu yang dibutuhkan untuk melakukan pencarian komponen lebih cepat 5 menit per harinya. Indikator operasional dari value chain operations adalah sebelum menerapkan SNI, jumlah produksi sebesar 800 unit/bulan. Setelah menerapkan SNI, jumlah produksi meningkat menjadi 1200 unit/bulan. Indikator operasional dari value chain outbound logistic adalah sebelum menerapkan SNI jumlah produk reject dapat mencapai 5\%. Setelah menerapkan standar, produk reject menurun menjadi $2 \%$. Indikator operasional dari value chain service adalah sebelum menerapkan standar, rasio klaim pertahun sebesar 5\%. Namun setelah menerapkan standar dan melakukan peningkatan berkelanjutan, keluhan dapat diturunkan menjadi $2 \%$. Indikator operasional dari value chain procurement adalah berkurangnya jumlah casing sebagai komponen yang rusak dalam satu tahun dimana sebelumnya casing yang rusak per tahun sekitar 25 pcs, saat ini berkurang menjadi sekitar 8 pcs yang rusak per tahun.

Setelah dilakukan identifikasi indikator operasional, maka dapat dilakukan perhitungan terhadap pengaruh indikator operasional. Perhitungan manfaat ekonomi penerapan standar pada UD. Deva Elektronik dipaparkan pada Tabel 5.

Tabel 5. Perhitungan Manfaat Ekonomi UD. Deva Elektronik

\begin{tabular}{|c|c|c|c|c|c|}
\hline No & Value Chain & Value Drivers & Dampak & Perhitungan (Per Tahun) & $\begin{array}{c}\text { Kuantifikasi (Per } \\
\text { Tahun) }\end{array}$ \\
\hline 1 & $\begin{array}{l}\text { Inbound } \\
\text { Logistic }\end{array}$ & $\begin{array}{l}\text { Kualitas } \\
\text { Penyimpanan }\end{array}$ & $\begin{array}{l}\text { Mempermudah proses } \\
\text { pencarian bahan baku dan } \\
\text { penyimpanan bahan baku lebih } \\
\text { baik }\end{array}$ & 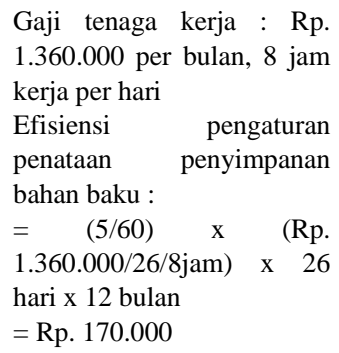 & Rp. 170.000 \\
\hline 2 & Operations & Efisiensi Produksi & Peningkatan jumlah produksi & $\begin{array}{l}\text { Sebelum penerapan standar: } \\
\text { jumlah produksi } 800 \text { unit per } \\
\text { bulan atau } 9.600 \text { unit per } \\
\text { tahun. Setelah penerapan } \\
\text { standar : jumlah produksi } \\
1200 \text { unit per bulan atau } \\
14.400 \text { unit per tahun. }\end{array}$ & Rp. 122.400 .000 \\
\hline
\end{tabular}




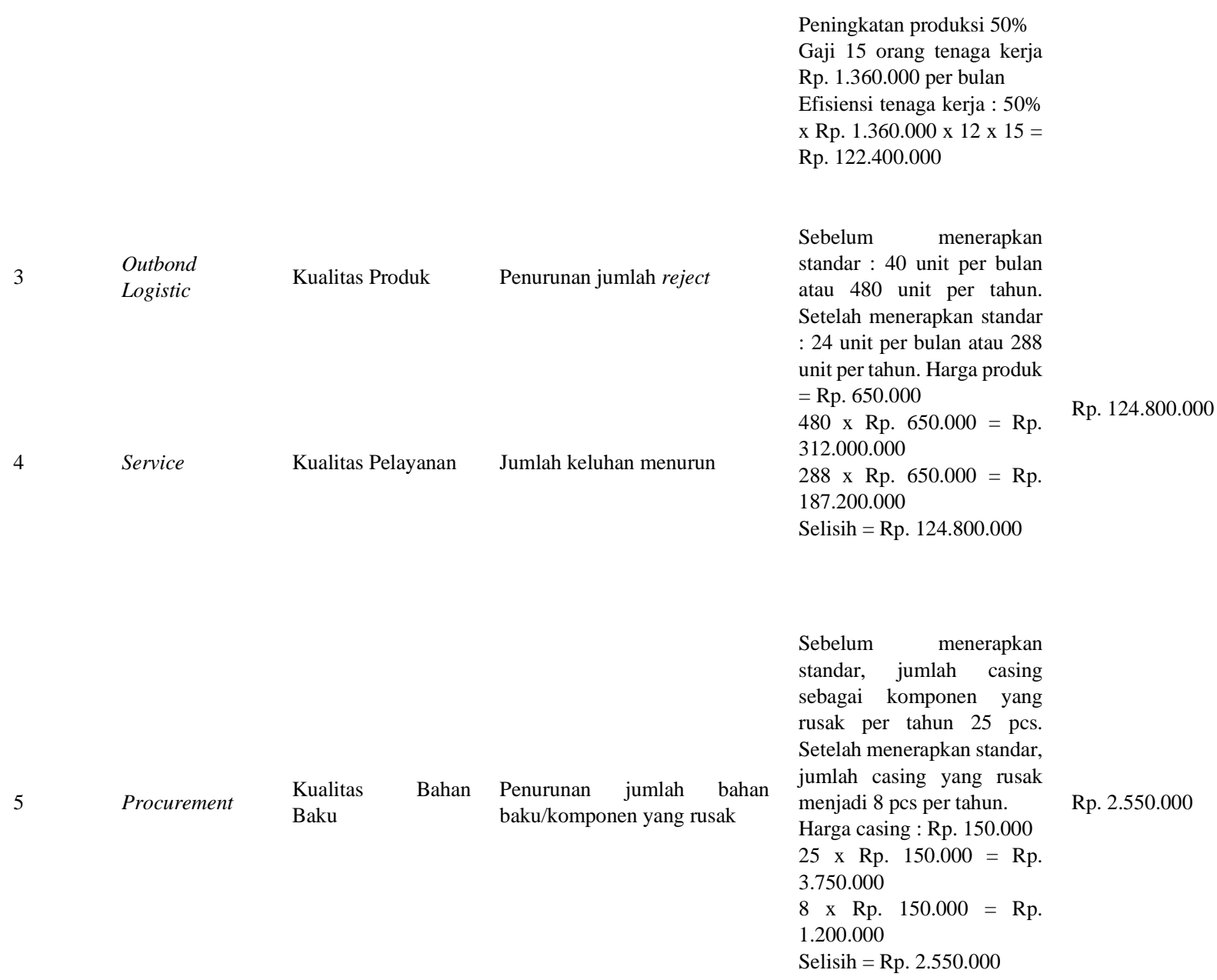

Berdasarkan hasil wawancara dengan expert UD. Deva Elektronik sesuai dengan value chain dan value drivers diperoleh hasil manfaat ekonomi dari penerapan standar. UD. Deva Elektronik memiliki lima value drivers yaitu kualitas cara penyimpanan, efisiensi produksi, kualitas produk, kualitas pelayanan, dan kualitas bahan baku. Value drivers kualitas cara penyimpanan dimana berdampak pada kemudahan dalam pencarian bahan baku/komponen dan penyimpanan bahan baku/komponen lebih baik setelah menerapkan SNI sehingga dapat mengurangi waktu untuk menemukan bahan baku/komponen tersebut memberikan manfaat ekonomi sebesar Rp. 170.000. Value drivers efisiensi produksi yang memberikan dampak berupa peningkatan jumlah produksi memberikan manfaat ekonomi sebesar Rp. 122.400.000. Value drivers kualitas produk dimana berdampak pada penurunan jumlah reject dan value drivers kualitas pelayanan yang memberikan dampak berupa jumlah keluhan pelanggan terhadap produk yang rusak menurun memberikan manfaat ekonomi sebesar 124.800.000. Value drivers kualitas bahan baku yang berdampak pada penurunan jumlah bahan baku/komponen yang rusak memberikan manfaat ekonomi sebesar Rp. 2.550.000. Manfaat dari penerapan standar pada UD. Deva Elektronik dapat dikatakan sudah cukup maksimal. Hal ini dapat terlihat dari hasil yang diperoleh dengan memiliki lima fungsi bisnis (value chain) yang memberikan dampak dari penerapan standar. Total keseluruhan manfaat ekonomi yang diperoleh UD. Deva Elektronik menjadi sebesar Rp. 249.920.000. Hasil tersebut dapat menjelaskan bahwa dalam penerapan standar dapat memberikan manfaat secara ekonomi bagi UKM penerap standar walaupun proses untuk memperoleh standar memerlukan waktu dan biaya yang tidak sedikit. Dalam proses awal untuk memperoleh SNI 04-6253-2003 memerlukan biaya untuk pengujian laboratorium, administrasi, dan akomodasi untuk pelaksanaan audit di lokasi UKM dapat mencapai Rp. 25.000.000 dimana angka tersebut dapat bertambah jika terdapat pengujian audit ulang. Dengan total manfaat ekonomi yang diperoleh UD. Deva Elektronik dapat dikatakan keuntungan yang diperoleh telah sebanding dengan biaya yang dikeluarkan untuk memperoleh SNI dan biaya lainnya terkait resertifikasi SNI setiap tahunnya.

\section{Kesimpulan}

Berdasarkan hasil penelitian, ISO Methodology Economic Benefit Standards dapat diterapkan pada Usaha Kecil dan Menengah (UKM) untuk menghitung manfaat ekonomi dari penerapan standar. Penerapan standar pada UD. Deva Elektronik memberikan manfaat ekonomi sebesar Rp. 249.920 .000 dalam satu tahun. Dengan total manfaat ekonomi yang diperoleh dapat 
dikatakan keuntungan yang diperoleh telah sebanding dengan biaya yang dikeluarkan untuk memperoleh SNI dan biaya lainnya terkait resertifikasi SNI setiap tahunnya. Berdasarkan hasil penelitian, maka saran yang dapat diberikan kepada pihak yang terkait dari penelitian ini yaitu untuk lebih meningkatkan manfaat ekonomi penerapan standar, UD. Deva Elektronik harus memaksimalkan fungsi bisnis yang lain seperti marketing and sales yang dapat memberikan dampak pada peningkatan jumlah penjualan dan berdasarkan hasil manfaat ekonomi penerapan standar pada UKM yang cukup besar, pemerintah pengelola UKM perlu melakukan sosialiasi untuk meningkatkan ketertarikan UKM dalam penerapan standar agar mampu bersaing dalam perdagangan global sehingga dapat memperoleh manfaat ekonomi yang besar kedepannya.

\section{Ucapan Terima Kasih}

Ucapan terima kasih kami sampaikan kepada UD. Deva Elektronik yang telah menyediakan tempat penelitian dan membantu memenuhi kebutuhan dalam kegiatan penelitian ini. Selain itu, ucapan terima kasih juga kami sampaikan pihak-pihak yang mendukung penelitian ini sehingga penelitian ini dapat berjalan dengan lancar dan selesai. Kami berharap penelitian ini dapat bermanfaat bagi para pembaca.

\section{Daftar Pustaka}

International Organization for Standardization. (2013). Economic Benefits of Standards ISO Methodology 2.0 . Geneva. https://www.iso.org/files/live/sites/isoorg/files/arc hive/pdf/en/pub100344.pdf. (Diakses 13 Juni 2021).

International Organization for Standardization. (2014). Economic Benefits of Standards. Geneva. https://www.iso.org/files/live/sites/isoorg/files/arc hive/pdf/en/ebs_case_studies_factsheets.pdf.

(Diakses 13 Juni 2021).

Meylani, Susanty, A., \& Rinawati, D. I. (2012). Penilaian Kesiapan UKM Batik Dalam Menerapkan SNI Batik (Studi Kasus: UKM Batik Solo dan Yogyakarta). Industrial Engineering Online Journal, $\quad$ Vol. $\quad 1, \quad$ No. 4. http://ejournals1.undip.ac.id/index.php/ieoj/article/ view/11 53. (Diakses 13 Juni 2021).

Mulyono, A. B., \& Pudjiastuti, U. (2013). Manfaat ekonomi Penerapan Standar di Sektor Makanan Menggunakan Metodologi ISO. Jurnal Standardisasi, Vol. 15, No. 1, hal. 66-81.

Perwitasari, Y., Fahma, F., \& Zakaria, R. (2019). Perencanaan Strategi Pengembangan SNI Berdasarkan Neraca Perdagangan, Standar Nasional, Struktur Industri Menggunakan Metode Analisis SWOT. Performa: Media Ilmiah Teknik Industri, Vol. 18, No. 2, hal 113-124.
SNI 04-6253-2003: Peralatan audio, video dan elektronika sejenis - Persyaratan keselamatan

Susanto, Danar. A., Isharyadi, F., \& Ritonga, M. (2017). Manfaat Ekonomi Penerapan Standar Pada Usaha Kecil Menengah Menggunakan ISO Methodology. Jurnal Standardisasi, Vol. 19, No. 1, hal 25-38.

Undang-Undang (2014) Undang-Undang Republik Indonesia Nomor 20 Tentang Standardisasi Dan Penilaian Kesesuaian.

Wikipedia. (2020). Usaha Kecil dan Menengah. https://id.wikipedia.org/wiki/Usaha_Kecil_dan_M enengah. (Diakses 12 Juni 2021). 
Halaman kosong 